\title{
The Musical and Aesthetic Concept \\ of the Portraits by V.A. Serov of Foreign Opera Singers of S. Mamontov's Theatre Company
}

\author{
Svetlana A. Yakovleva* \\ Krasnoyarsk State Institute of Arts \\ 22 Lenin Str., Krasnoyarsk, 660049, Russia
}

Received 15.01.2017, received in revised form 27.07.2017, accepted 07.08.2017

The article suggests the study of the musical and aesthetic interpretation of the portraits by V.A. Serov of foreign singers of S.I. Mamontov's opera theatre. Special attention is given to the issue of unity and mutual influence of musical and visual art. The most important problems of the aesthetics of correlation and interpenetration between the arts are considered. The research approach to the study of the issue of mutual influence in the system of arts includes two most important aspects: musicological, which allows to reveal the features of the musical embodiment, and the pictorial image. The article considers the formation of theatrical thinking, the director's school of S.I. Mamontov based on the creation of an artistic image, that with the existence of the independence of the arts, their synthesis reflects unity in solving historical problems and aesthetic exploration of the world. The article analyzes foreign vocal schools reflecting the main tendencies of $19^{\text {th }}$ century European singing culture. The expressive means of subordinating the musical model to the artist's pictorial method are analyzed in detail. This research approach makes it possible to confirm the semantic connections of works of musical and pictorial art.

Keywords: artist Valentin Aleksandrovich Serov, private opera of Savva Ivanovich Mamontov, Angelo Masini, Francesco Tamagno, Marie van Zandt, António de Andrade, tenor, soprano.

DOI: 10.17516/1997-1370-0125.

Research area: culturology, art criticism.

Many outstanding cultural persons, scholars and art historians A.N. Benois, I.E. Grabar', N.I. Punin, A.M. Efros, A.A. Nedoshivin, D.V. Sarabyanov, O.A. Lyaskovskaya, V.A. Lenyashin and many others addressed the creative heritage of V.A. Serov (1865-1911). It is difficult to name a poorly studied area in the artist's creative path.

The works of the 1910s-1930s are characterized by the nature of the creative essay and biography, their artistic and literary merit is based on the personal view of the artist's contemporaries. Since the 1930s the amount of factual material gets larger, the systematization of printed publications is organized and the image of the classic artist is formed. Since the 1960s, a number of authors had been trying to provide scientific and rational understanding of Serov's art, a genre specific approach to his heritage. Expansion of the idea

(C) Siberian Federal University. All rights reserved

* Corresponding author E-mail address: masdisf555@mail.ru 
of Serov's opera singers' portraits, the concept of portraits, their psychological structure is based on the memoirs of the artist's contemporaries I.E. Repin, K.A. Korovin, I.S. Ostroukhova, V.D. and E.D. Polenovy and many others.

When speaking about Serov as a portraitist in terms of general and analytical presentation of the characteristics the researchers always mention the well-known portraits, including those of Italian singers Masini and Tamagno. In monographic studies, V.A. Lenyashin evaluated the evolution of the portraitist, reasonably analyzed the art process in the context of the epoch and the individual features of the artist.

The art of Serov was associated with the role of musical culture in the artist's biography. The creative atmosphere of childhood and adolescence becoming a natural environment, had a certain influence on the development and formation of the artist, modeling of genre priorities. The idea of Serov's portrait art is considered widely and reasonably understood and, following Grabar's assessment of the artist's works, "each of them could be an object of a whole individual study" (Grabar', 1914: 135), one should address the problems of the musical and aesthetic interpretation of portraits of foreign opera singers of S. Mamontov's theatre.

The musical and artistic environment of Serov developed certain style and composition trends, conditioned by the creative context of the epoch and, above all, by the artist's individual and philosophical approach. V. Vanslov addressed the problem of correlation and interaction of the arts proceeding from general aesthetic understanding. The relevance of the topic lies in the search for the methods of musical and aesthetic interpretation of the images of opera singers in the portraits by Serov. Methods of artistic and structural research will allow to open images through the search for the unity of compositional techniques and artistic forms in painting and music.
Many portraits of the 1890s of Masini (1890), Tamagno (1891), Korovin (1891), S.A. Tolstoy (1892), Z.V. Moritz (1891-1892), Levitan (1893), V.V. Musina-Pushkina (1895), grand duke Pavel Aleksandrovich (1897) and others are stylistically ambiguous in reproducing the internal style, the search for a pictorial method. The analytical and psychological approach of the artist to the model was inferior to purely pictorial qualities, and "the search for the character comes to the foreground" (Grabar', 1914: 130). Steady inertia of thinking is confirmed by authoritative estimates. Looking deeper into Serov's heritage and a wide range of analyzed issues, without repeating the truth of what has been said, it is possible to broaden understanding at the level of the musicological interpretation of foreign opera singers of S.I. Mamontov's theatre.

S.I. Mamontov's Russian private opera (1841-1918) for its time was distinguished by novelty and tendency to mutual influence and correlation of musical and visual arts so typical for the artistic field. Acquaintance of Serov with Mamontov begins in Rome and continues in the estate of philanthropist Abramtsev. The phenomenon of the Mamontov's theatre struck by its scenic unity and consistency, especially with regard to the Russian composing and vocal schools. Progressiveness consisted in the integrity of the artistic thought, democratization of the theatrical art, and, despite the share of non-professionalism, “... in a way, Mamontov's influence was similar to the influence of Stanislavsky on drama" (Rakhmaninov, 1978: 57).

In Mamontov's art club the artists Repin, Korovin, Levitan, Vasnetsov, Vrubel and Polenov were engaged in decorations, sketches for costumes, arts and crafts, painted their famous works. Mamontov's art club attracted representatives of various types of art creating interaction and an organic union in a single 
artistic space. For Serov the beginning of his creative path is inseparable from Abramtsev, the estate of V.D. Derviz in Domotkanovo.

Serov received basic academic knowledge from the recognized teachers of the Imperial Academy of Arts P.P. Chistyakov, I.E. Repin. Serov was enrolled to the Academy as an auditor in 1880 in the studio of P. Chistyakov known by its students V.I. Surikov, I.E. Repin, V.D. Polenov, V.M. Vasnetsov, M.A. Vrubel and others. Chistyakov laid the foundation for his knowledge of the picture, the beginning of the visual image. The structural basis of the artist's pictorial form had a rational and intellectual approach to the model, which was reflected in one of his first works "The portrait of the artist P.P. Chistyakov" (1881). According to Chistyakov's technique, a drawing was created (Fig. 1) differing in the coordinated use of various pictorial means: "Serov was still a student, when the wise priest of painting P.P. Chistyakov was repeatedly surprised by this harmony ... Chistyakov had often repeated that he had not yet met another person with such an equal measure of overall artistic comprehension, which was given to Serov's by nature" (Valentin, 1971: 31).

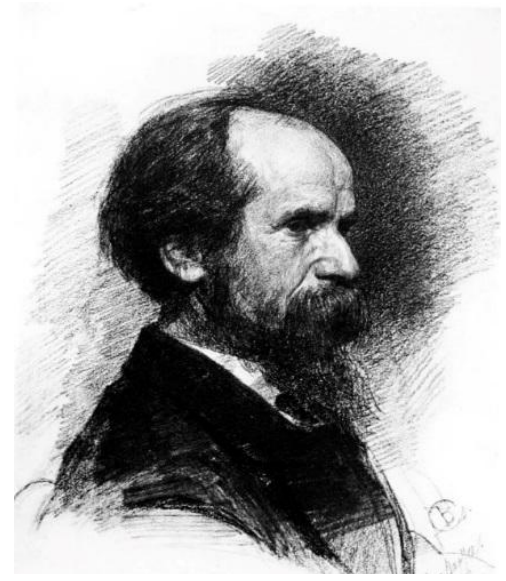

Fig. 1. V.A. Serov. The portrait of the artist P.P. Chistyakov. 1881. Drawing. The State Tretyakov Gallery
In the first adolescent works "The Portrait of A.Ya. Simonovich" (1880), "Humpback” (1880), "The Portrait of V.A. Repin" (1881) Repin's lessons are noticeable and the artist's analytical line is outlined. In 1885, on a foreign trip, Serov got acquainted with the artists of the European school, copied the works of Velasquez, and later the classic samples would become an aesthetic criterion in his creative work.

Mamontov's private opera was opened in January 1885 by A.S. Dargomyzhsky's "The Mermaid". Mamontov was "born to be a director" (Rakhmaninov, 1978: 55) and made great efforts in theatrical direction - the foremost phenomenon of the Russian theatre. The director's experiments turned to the innovative concept of a single organism-ensemble, where the priority role was assigned to opera and stage skills. Mamontov tried to introduce lively and natural performing art as an alternative to the formalitiy of opera masterhood in the leading theatres of the country. An innovative project included the selection of the first-class foreign and Russian singers with a bright stage appearance to the vocal group. The effective side sometimes replaced the musical and scenic integrity of the image.

The Portuguese, Francesco brothers (18591921) and Antonio d'Andrade (1854-1942), successfully performed as a part of the Italian Mamontov's company. Antonio d'Andrade's gorgeous appearance and artistry met the artistic taste of the patron. Serov created the portrait of the singer with "gorgeous appearance" (Valentin, 1971: 65) in 1885, during ten days, and the same year it was exhibited at the $5^{\text {th }}$ periodic exhibition of the Moscow Society of Lovers of Fine Arts (Fig. 2).

Opera practice of A. d'Andrade began in Lisbon, in 1881, he took lessons from the famous singer and teacher Sebastiano Ronconi in Italy. Timbre colouring of his voice allowed him to sing tenor roles of Roberto in "Willis" by G. Puccini, 


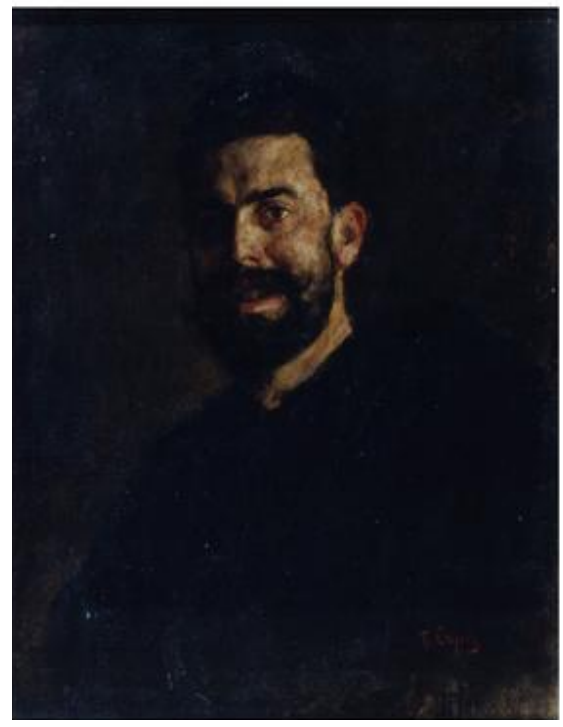

Fig. 2. V.A. Serov. The portrait of the singer Antonio d'Andrade. 1885. Sumy regional art museum named after N. Onatsky

Fernand in "La favorite", Gennaro in "Lucrezia Borgia" by Gaetano Donizetti, the Duke in "Rigoletto", Radames in "Aida" by G. Verdi, Don Jose in "Carmen" by J. Bizet, Faust in the opera of the same name by S. Gounod, etc. Since the middle of the $19^{\text {th }}$ century there had been transformations in the vocal art of Italy. Giuseppe Verdi's school of composers united previous achievements and developed common principles of music art. The artistic level required emotional impact on the viewer with the integrity of the music, libretto, vocal and expert features of the singer, so that the "mezzo-soprano was a great artist” (Verdi, 1973: 193).

In assessing the vocal and appearance features of the singer, the Moscow public, the environment of Mamontov and colleagues on stage agreed in the following: when interpreting the stage image while having insignificant voice and sound, he won with elegant finishing of the phrase, the form of refined sound and vivid performance. The shades of "pianissimo" were regarded as a muted tenor, but the catchy appearance for

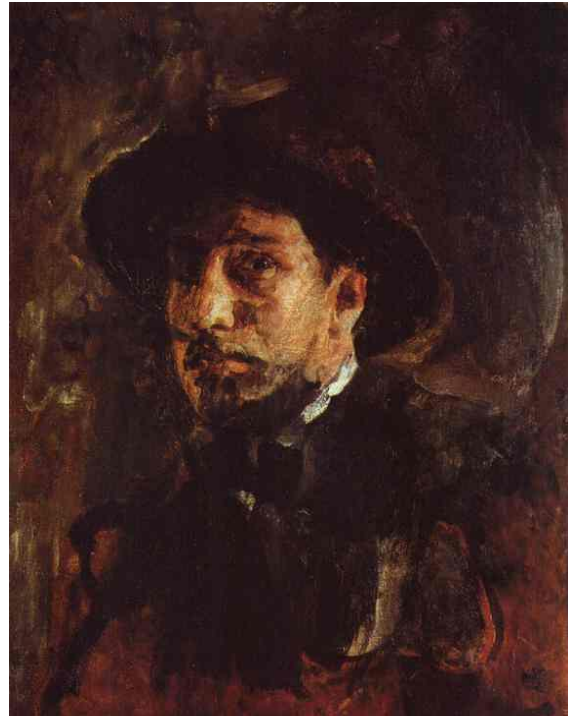

Fig. 3. V.A. Serov. Self-portrait. 1885. Private collection

the performance of leading parties sometimes played the decisive role.

Serov's work was first demonstrated in Moscow. Articles in mass media noted similarities, picturesque dignities had ambiguous criticism: "interesting" to "rough" painting (Valentin, 1971: 160). During these years, the artist had developed his own method combining Repin's influence, achievements of old masters and understanding new forms. Serov painted the portrait of A. d'Andrade immediately after a foreign trip, when he got aquainted with the collections of museums, paintings by Rubens, Rembrandt, Titian, Anthony van Dyck. “... I am copying Velazquez” (Valentin, 1985: 52). The portraits of V.A. Repin (1882), Lyudmila Mamontova (1884) demonstrate new understanding of the portrait form and tonal system in the depiction of the singer and "Selfportrait" (Fig. 3).

Solving the task of the form gave the impression of sketching and incompleteness. "It was not a portrait, but a sketch" because of the lack of time for posing and the impossibility of capturing the physiognomic properties of the 
model. "I wanted to depict laughing d'Andrade" (Grabar', 1965: 69). The artist caught the character of the singer, who used his bright and spectacular appearance while creating a stage image. Though having modest vocal potential, he was able to use contrast dynamics and a variety of timbres, capturing the audience with his scenic and actor's charm.

At the same time when d'Andrade brothers came to Mamontov's theatre, Marie van Zandt (1861-1919) was invited to Mamontov's private opera. A brilliant coloratura soprano and charming appearance favoured performances in theatres of Italy, France, England and Russia in the leading roles of Zerlina in "Don Giovanni" by W. Mozart, Marguerite in "Faust", Juliet in "Romeo and Juliet" by S. Gounod, Ophelia in "Hamlet", Mignon in "Mignon" by Sh. Tom, Dinora by J. Meyerbeer. The composer Leo Delibes wrote the opera "Lakme" for Marie van Zandt taking into account her natural background and her knowledge of the theoretical French singing school.

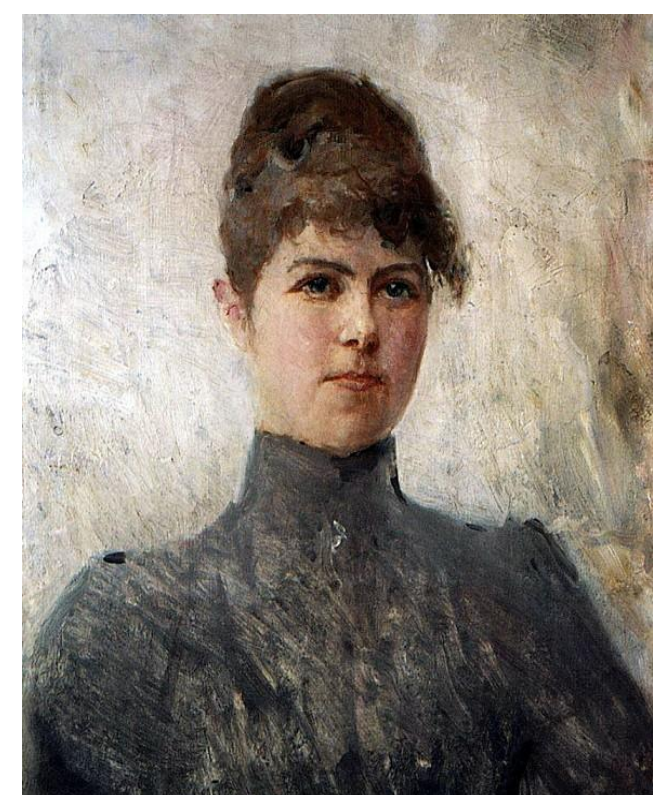

Fig. 4. V.A. Serov. Portrait of Marie Yakovlevna van Zandt. 1886. Samara Art Museum
The portrait is characterized by features of a sketch in gray-ash colours (Fig. 4). It was impossible to implement the idea of a fulllength portrait due to the spoiled nature and capriciousness of the singer, she was "bored with posing to a completely unknown artist" (Grabar', 1914: 69, 73), which affected the artificiality of the image, the hidden psychological essence. The absence of spiritual contact has led to a discrepancy between the model and scenic images.

Possessing a wide musical horizon and taste, Serov was fascinated with the actor's talent of the singer, a rare ability of transformation, professional qualities and voice properties. Contemporaries enthusiastically spoke about her brilliant vocal data, dramatic emotional range from tragic to comic. Creative personal conviction - "search for the character" - is the evidence of the objectivity of the artist, which emphasized "capriciousness" in the pursed lips, playful eyes, “... what can be done if the caricature is in the model herself” (Grabar', 1965: 157). The lyrical coloratura soprano with a gentle and intimate voice, vibrating, with light overflows, the voice is shaded with exquisite coloristic nuances of the transparent watercolour tonality: "Colour nature ... has the ability to influence sensory perception ... is able to aesthetically affect a person" (Isaeva, 2012: 33).

After the end of the theatrical season in 1887, Mamontov worked with singers of Italian private theatre company. The posters attracted the public with the name of the Italian tenor Angelo Masini (1844-1926). The vocal possibilities of Masini were revealed in Radames's parties in "Aida" by G. Verdi, Almaviva in "The Barber of Seville" by G. Rossini, Ferdinand in "La favorite", Nemorino in "The Love Drink" by G. Donizetti, Turiddu in "Cavalleria rusticana" by P. Mascagni, which brought him European fame. 
In the Italian private theatre companies of Mamontov he performed the roles of Lohengrin, Rigoletto in the operas of R. Wagner, G. Verdi, Almaviva, Ferdinand. Shalyapin noted the beauty of the timbre, the richness of shades: "he really sang, like an archangel sent from heaven ... I never heard such singing again" (Fedor, 1976: 139).

Serov started to work on the portrait (Fig. 5) on the order of Mamontov in 1890, on the $10^{\text {th }}$ periodic exhibition of the Moscow Society of Lovers of Arts he received the first prize for this work. In the 1890 s Serov achieves colour and plastic agreement in the composition, revealing the most valuable for the artist - sharpness of the characteristics. Serov's approach to the model was known in the artistic environment: to reveal the essential without hurrying, studying and peering at the person he portrayed. The artist revealed the personality of the model with an artistic appearance, capricious and accustomed to the fulfillment of his desires, amiable, sweet and courteous in the studio.

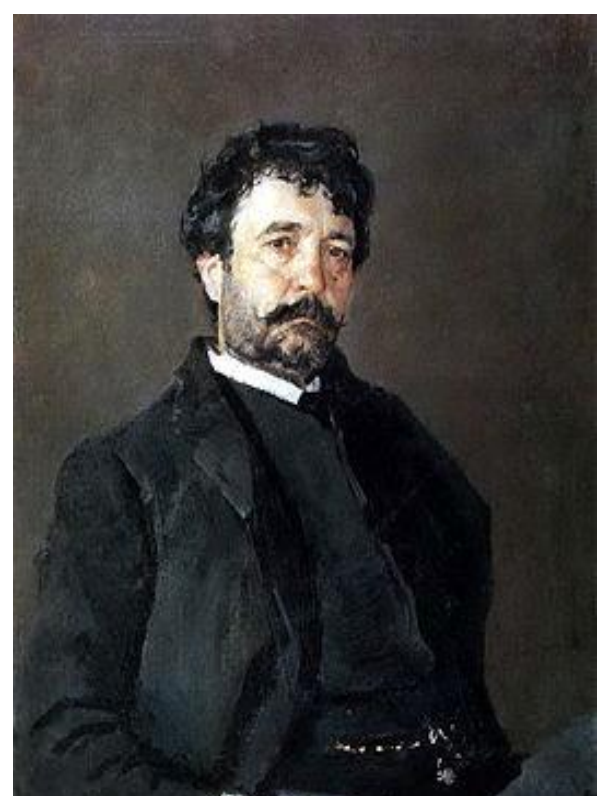

Fig. 5. V.A. Serov. The portrait of Angelo Masini. 1890. The State Tretyakov Gallery
The emotional tone of the picture is achieved by means of compositional techniques. The composition was distinguished by reasoning of every detail of the portrait. It was important to set the figure in the centre with the turn from left to right at an angle in depth and a diagonal solution from the bottom right to the upper corner. This gave the figure an impression of pleasant importance and slight movement due to the hands in the pockets of the trousers and the knee bent, ready to push off from the invisible support, thereby reinforcing the image of the singer spoiled by the public. According to the memoirs of Mamontov's contemporaries, the singer impressed with the beauty of sound and technical skill, but not with the drama of the image remaining arrogant at the stage and in everyday life.

Masini's lyrical and dramatic tenor is filled with smooth transitions and bright coloration of the sound, the clarity of the melodic technique of bel canto that conquered the Russian audience. A pretentious and self-willed character led to the break of the singer with Mamontov's company. The uniqueness of the portrait is in the truthfulness, insight and uncompromising hand of the artist.

The artistic environment responded positively to the portrait, and Serov found it "not bad ... this is the best of my portraits" (Valentin, 1985: 178). The coloristic decision in grayblack tones, the use of free and confident brush movement echo with the aesthetic criteria of the old European masters.

Due to the break with Angelo Masini for the season of 1891, Mamontov invites tenor Francesco Tamagno (1850-1905) to join the company. Tamagno's voice sounded on the world stages in the roles of Arnold in "Wilhelm Tell" by G. Rossini, Edgar in "Lucia di Lammermoor", Gennaro in "Lucretia Borgia" by G. Donizetti, Verdi's operas "Aida", "Ball Masquerade", "Ernani”, “Troubadour”, "Don Carlos". Tamagno 
and Verdi were bound by special creative relations. Their correspondence testifies to the preparation of the role of Othello for the premiere at the La Scala Theatre in 1887.

In the opera works of the composer the main factors in creating musical drama, were melody and dramatic truth. Shakespeare's material found a worthy embodiment in the works of Verdi. There are no complicated vocal passages in operas, the composer avoided bright falsetto sounds, therefore in the letter about Othello's role the composer answered Masini delicately: “... arrange your affairs ... not counting on the vague possibilities of "Othello"' (Verdi, 1973: 251). Tamagno, the owner of a strong voice, dramatized the aria, adapted the emotional intensity and voice apparatus to the embodiment of the hero of the Shakespeare's drama. The singer with his outstanding potential - tall, manner, powerful sound, bright high notes - exactly corresponded to Othello's image.

Serov heard Tamagno in Venice, in Moscow, and on the order of Mamontov painted the portrait,

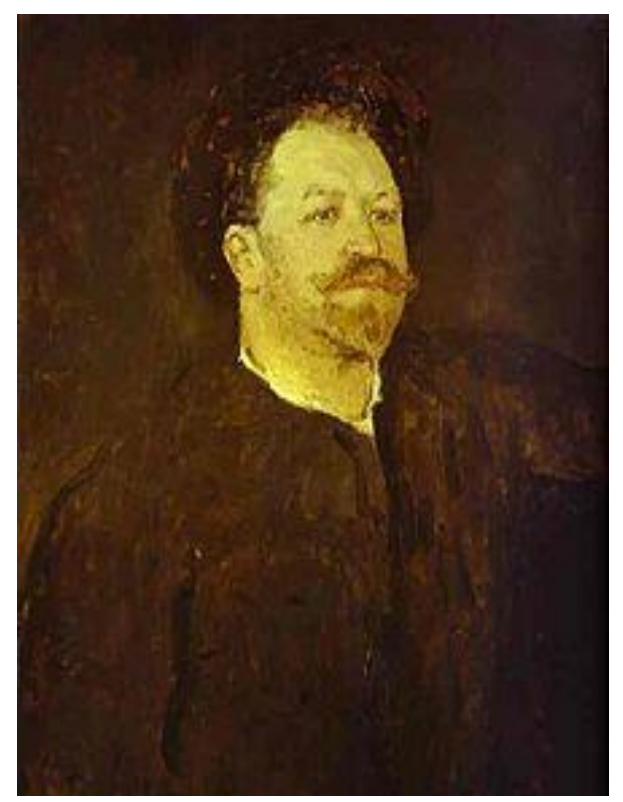

Fig. 6. V. Serov. The portrait of Francesco Tamagno. 1891. The State Tretyakov Gallery which was duly appreciated by critics and artists. Tretyakov wished to get work for the collection. The figure of the singer is difficult to fit into the picture space, that is why the composition becomes impressive, as well as the overwhelming power of the voice according to the memoirs of K. Stanislavsky.

The sounds of the "trumpet" came from the throat, and Serov focused on the face with a powerful naked neck, the "instrument" of the famous tenor. In the gallery of portraits of foreign singers Serov creates a detailed picture of the face and figure, a heroic large silhouette with the psychological centre of the composition - the face of the singer: this allows to achieve striking accuracy and revealing of the spiritual essence. One of the principles in the artist's painting was the search, evaluation and adherence to the classical laws of painting. The tonal-pictorial approach in the portrait of the singer was distinguished by the translucence of the glaze, and this gave the colour value to the face on the dark background.

Serov sharpened his skills bringing portraits to perfection. Portraits of foreign singers of Mamontov's opera company were painted after Serov's trip to Europe (d'Andrade, 1885); before canonical "Girl with Peaches" (1887), "Girl Lighted by the Sun" (1888), he painted the portrait of the singer Marie van Zandt (1886) and in the early 1890 s he painted the portraits of the tenors Masini and Tamagno. The evolution of the master in the artistic context of the epoch is seen, the upbringing of the sense of perfection of the portrait form, the tonal-pictorial approach, the accuracy of physiognomic features, the truthfulness of the characteristic features. Aesthetic ideal for the artist was the European classic school.

The composition of portraits, the coloristic possibilities had sharpened the individuality, the spiritual system, the emotionality of the portrayed persons. The undertaken research allows to draw 
a conclusion that comparing the vocal art and painting on the artistic-structural and artistic- historical levels, one can note the image-style unity in the culture of the late $19^{\text {th }}$ century.

\section{References}

Fedor Ivanovich Shaliapin [Fedor Ivanovich Shalyapin] (1976-1979). Moscow, Iskusstvo, 1752 p.

Grabar', I.E. (1914). Valentin Aleksandrovich Serov: zhizn' i tvorchestvo [Valentin Aleksandrovich Serov: life and creative work]. Moscow, I. Knebel', 299 p.

Grabar', I.E. (1965). Valentin Aleksandrovich Serov: zhizn' i tvorchestvo 1865-1911 [Valentin Aleksandrovich Serov: life and creative work 1865-1911]. Moscow, Iskusstvo, 489 p.

Isaeva, N.V. (2012). Estetika tsveta v istorii kul'tury [The aesthetics of colour in the history of culture]. In Voprosy kul'turologii [Culture Study Issues], 6, 33-36.

Konstantin Koronin (1963). Zhizn' i tvorchestvo, pis'ma, dokumenty, vospominaniia [Life and creative work, letters, documents, memoirs]. Moscow, Akademiia khudozhestv SSSR, 564 p.

Lauri-Vol'pi, Dzhakomo (1972). Vokal 'nye paralleli [Vocal parallels]. Leningrad, Muzyka, 303 p.

Leniashin, V.A. (1986). Portretnaia zhivopis' V.A. Serova 1900-kh godov. Osnovnye problemy [Portrait art of V.A. Serov of 1900s. Basic problems]. Leningrad, Khudozhnik RSFSR, 260 p.

Leniashin, V.A. (1989). Valentin Aleksandrovich Serov [Valentin Aleksandrovich Serov]. Leningrad, Khudozhnik RSFSR, 248 p.

Rakhmaninov, S.V. (1978). Literaturnoe nasledie. V 3 t. T. 1. Vospominaniia. Stat'i. Interv'iu. Pis'ma [Literature heritage. In 3 volumes. Volume 1. Memoirs. Articles. Letters]. Moscow, Sovetskii kompozitor, $668 \mathrm{p}$.

Rossikhina, V.P. (1985). Opernyi teatr S. Mamontova [S. Mamontov's opera theatre]. Moscow, Muzyka, 238 p.

Salina, N.V. (1941). Zhizn“ $i$ stsena [Life and stage]. Moscow, Leningrad, VTO, 184 p.

Sarab'ianov, D.V. (2001). Russkaia zhivopis' kontsa XIX-nachala XX veka. [Russian pictorial art of the end of the $19^{\text {th }}$ - beginning of the $20^{\text {th }}$ centuries]. Moscow, Galart, $284 \mathrm{p}$.

Solovtsova, L.A. (1981). Dzhuzeppe Verdi [Giuseppe Verdi]. Moscow, Muzyka, 416 p.

Valentin Aleksandrovich Serov. Al'bom [Valentin Aleksandrovich Serov. Sketchbook] (1973). Moscow, Iskusstvo, $32 \mathrm{p}$.

Valentin Serov $v$ perepiske, dokumentakh i interv'iu [Valentin Serov in correspondence, documents and interviews] (1985). Leningrad, Khudozhnik RSFSR, 448 p.

Valentin Serov v vospominaniiakh, dnevnikakh i perepiske [Valentin Serov in memoirs, notebooks and correspondence] (1971). Leningrad, Khudozhnik RSFSR, 717 p.

Vanslov, V.V. (1977). Izobrazitel'noe iskusstvo i muzyka [Pictorial art and music]. Leningrad, Khudozhnik RSFSR, 294 p.

Verdi, G. (1973). Izbrannye pis'ma [Selected letters]. Leningrad, Muzyka, 352 p. 


\title{
Музыкально-эстетическая концепция
}

\author{
портретов B.A. Серова \\ зарубежных оперных певцов \\ труппы театра С. Мамонтова
}

\section{С.А. Яковлева}

Красноярский государственный институт искусств Россия, 660049, Красноярск, ул. Ленина, 22

Статья предлагает исследование музыкально-эстетической интерпретации портретов В.А. Серова зарубежных певцов оперного театра С.И. Мамонтова. Особое место уделено вопросу единства и взаимовлияния музыкального и изобразительного искусства. Рассматриваются важнейшие проблемы эстетики соотношения и взаимопроникновения между искусствами. Исследовательский подход к изучению вопроса взаимовлияния в системе искусств включает два важнейших аспекта: музыковедческий, позволяющий выявить особенности музыкального воплощения, и живописного изображения. Освещается формирование театрального мышления режиссерской школь С.И. Мамонтова, основанной на создании художественного образа при существовании самостоятельности искусств, их синтез отражает единство в решении исторических задач и эстетического освоения мира. В статье анализируются зарубежные вокальные иколь, отражающие основные тенденции певческой европейской культуры ХІХ в. Подробно разбираются выразительные средства подчинения музыкальной модели живописному методу художника. Данный исследовательский подход дает возможность подтвердить смысловые связи произведений музыкального и живописного искусства.

Ключевые слова: художник Валентин Александрович Серов, частная опера Саввы Ивановича Мамонтова, Анджело Мазини, Франческо Таманьо, Мария Ван-Занд, Антонио дАндраде, тенор, сопрано.

Научная специильность: 24.00.00-культурология, 17.00.00-искусствоведение. 